\title{
NITROGEN CONCENTRATIONS AND NITROGEN YIELDS OF ABOVE- GROUND DRY MATTER OF CHICKPEA DURING CROP GROWTH COMPARED TO PEA, BARLEY AND OAT IN CENTRAL EUROPE
}

\author{
R.W. Neugschwandtner ${ }^{*}, H$. Wagentristl $^{2}, H .-P$. Kaul $^{1}$ \\ ${ }^{1} B O K U$ - University of Natural Resources and Life Sciences, Vienna, Department of Crop Sciences, \\ Division of Agronomy, Tulln, AUSTRIA \\ ${ }^{2}$ BOKU - University of Natural Resources and Life Sciences, Vienna, Department of Crop Sciences, \\ Experimental Farm Groß-Enzersdorf, Groß-Enzersdorf, AUSTRIA \\ ${ }^{*}$ Corresponding author: reinhard.neugschwandtner@boku.ac.at
}

Received: 06.01.2014

\begin{abstract}
Alternative crops like chickpea could become of interest under Pannonian climate conditions in Central Europe due to forecasted changes in climate. Therefore a two-year trial was conducted to evaluate concentrations, uptake and yields of nitrogen $(\mathbf{N})$ during crop growth of chickpea (Cicer arietinum $\mathbf{L}$.) compared to pea (Pisum sativum L.), barley (Hordeum vulgare L.) and oat (Avena sativa $\mathbf{L}$.) as affected by $\mathbf{N}$ fertilization with either calcium ammonium nitrate (CAN) or the depot fertilizer Basacote ${ }^{\circledR}$ Plus 6M (DF) in eastern Austria. Chickpea had the lowest above-ground dry matter (AGDM) and $\mathbf{N}$ yields among the four crops in 2006; however, it could gain higher AGDM and $N$ yields than those of barley and oat under drought conditions in 2007. $N$ concentrations and $N$ yields throughout crop growth were increased by increasing rates of $\mathbf{N}$ fertilization (with CAN showing generally higher values than DF). Chickpea had a high crop $\mathrm{N}$ uptake rate and a high relative $N$ uptake rate even under drought conditions. Thus, results indicated that chickpea could be an alternative crop in dry environments for achieving reasonably $\mathbf{N}$ yields in Central European growing conditions.
\end{abstract}

Keywords: Chickpea, Cicer arietinum, nitrogen, uptake rate, Central Europe

\section{INTRODUCTION}

Expected changes in agro-climatic conditions and a substantial deficit of protein sources for livestock are two challenges for European agriculture. The changes in agroclimatic conditions in Central Europe are expected to go along with an increase in air temperature, changes in the amount and distribution of precipitation, and prolonged growing seasons. This may lead to a lower productivity of rainfed spring crops due to a higher risk of drought (Trnka et al., 2011). Promising opportunities may arise under these conditions for adopting crops with a pronounced warm-season growth habit such as chickpea (Cicer arietinum L.) in comparatively cool, northern latitude areas (Gan et al., 2009). Introducing a new grain legume to Central European agricultural systems would be also beneficial for reducing the substantial deficit of protein sources in the European Union where around two-thirds of soybean meal and soybeans [Glycine $\max (\mathrm{L}$.) Merr.] for livestock feed is imported (Henseler et al., 2013).

Chickpea is mainly produced in arid or semiarid environments (Canci and Toker, 2009a, b). Due to several morphological and physiological advantages, the crop can effectively cope with drought conditions (Serraj et al., 2004; Cutforth et al., 2009; Zaman-Allah et al., 2011). Chickpea is of high importance in human diets in many areas of the world. Additionally, chickpea grains can be used as energy and protein-rich feed in animal diets and chickpea straw as forage for ruminants (Bampidis and Christodoulou, 2011). Chickpea yields, yield components and protein contents are affected by production system and fertilization regime (Caliskan et al, 2013).

Although chickpea is not a common crop in Central Europe, it could provide an alternative for food and feed protein production in the face of climate change. Recently, the plant has been introduced to semiarid regions in Australia (Siddique and Sykes, 1997), to the Northern Great Plains in North America (Miller et al., 2002) and in western Canada (Anbessa et al., 2007). In eastern Austria, chickpea can achieve higher grain and straw yields than spring sown barley (Hordeum vulgare L.) and oat (Avena sativa $\mathrm{L}$.) under drought conditions (Neugschwandtner et al., 2013). Furthermore, the adoption of chickpea in Central Europe could lead to crop diversification and improved productivity of sustainable agricultural systems as legumes satisfy a bulk of their $\mathrm{N}$ demand from 
atmospheric $\mathrm{N}$ through symbiosis with $\mathrm{N}$ fixing rhizobia. Thereby the demand for $\mathrm{N}$ fertilizer inputs within crop rotations is minimized (van Kessel and Hartley, 2000), and positive yield effects are caused through the transfer of biologically fixed $\mathrm{N}$ via crop residues to subsequent non-legume crops (Kaul, 2004).

Currently, little information exists on the agronomy and the performance of chickpea grown in northern latitudes (Gan et al., 2009). Therefore, the objective of the presented work was to evaluate $\mathrm{N}$ concentrations, $\mathrm{N}$ yields and $\mathrm{N}$ uptake of chickpea during crop growth under Central European growing conditions as compared to pea, barley and oat and as affected by fertilizer form and fertilizer rate to gain information for a possible introduction of this crop to Central Europe.

\section{MATERIAL AND METHODS}

\section{Experimental site and weather conditions}

The experiment was carried out in Raasdorf ( $48^{\circ} 14^{\prime}$ $\mathrm{N}, 16^{\circ} 33^{\prime} \mathrm{E}$; altitude: $153 \mathrm{~m}$ a.s.l.) in eastern Austria at the experimental farm of BOKU University. The soil is classified as a chernosem of alluvial origin and rich in calcareous sediments ( $\mathrm{pH}$ 7.6). The texture is silty loam; the content of organic substance is at $2.2-2.3 \%$.

The mean annual temperature is $10.6^{\circ} \mathrm{C}$, the mean annual precipitation is $538 \mathrm{~mm}$ (1980-2009). Table 1 shows the long-term average monthly temperatures and precipitation from February to July and the deviations

Table 1. Long-term average monthly temperature and precipitation (1980-2009) and deviations during the 2006 and 2007 growing seasons

\begin{tabular}{|c|c|c|c|c|c|c|}
\hline & \multicolumn{3}{|c|}{ Temperature $\left({ }^{\circ} \mathrm{C}\right)$} & \multicolumn{3}{|c|}{ Precipitation (mm) } \\
\hline & $\begin{array}{l}\text { Long term mean } \\
(1980-2009)\end{array}$ & $\begin{array}{c}2006 \\
( \pm)\end{array}$ & $\begin{array}{c}2007 \\
( \pm)\end{array}$ & $\begin{array}{c}\text { Long-term mean } \\
(1980-2009)\end{array}$ & $\begin{array}{c}2006 \\
( \pm)\end{array}$ & $\begin{array}{c}2007 \\
( \pm)\end{array}$ \\
\hline February & 1.7 & -1.9 & 3.8 & 26.4 & -7.7 & 17.7 \\
\hline March & 5.8 & -2.1 & 2.3 & 38.5 & 7.7 & 28.0 \\
\hline April & 10.7 & 1.3 & 2.1 & 35.3 & 30.3 & -34.4 \\
\hline May & 15.6 & -0.5 & 1.6 & 56.1 & 16.7 & -9.8 \\
\hline June & 18.5 & 0.6 & 2.8 & 72.3 & -9.9 & -3.9 \\
\hline July & 20.8 & 2.8 & 1.9 & 59.1 & -52.3 & -6.2 \\
\hline
\end{tabular}

during the 2006 and 2007 growing seasons. The temperature was considerably higher in 2007 than in 2006 (except for July). Monthly precipitation was well above average in March and April in 2006. Contrary to that, the growing season 2007 was characterized by a severe spring drought without rainfall from the end of March to the beginning of May.

\section{Experimental factors}

Two chickpea genotypes were tested under different $\mathrm{N}$ fertilization in comparison to common varieties of pea and the non-legume crops barley and oat with similar vegetation periods. The experiment was set up in a randomized complete block design with two replications. The chickpea variety Kompolti and commercial seeds of a chickpea genotype of unknown origin obtained from a trade company were planted (both are Kabuli type chickpeas). The seeds had been multiplied on-farm. Pea cv. Attika and Rosalie, barley cv. Xanadu and oat cv. Jumbo were used as standards of comparison. The nitrogen fertilizer calcium ammonium nitrate (CAN) $(27 \%$ $\mathrm{N}, 10 \% \mathrm{Ca}$ ) and the depot fertilizer Basacote ${ }^{\circledR}$ Plus $6 \mathrm{M}$ (DF) $(16 \% \mathrm{~N}, 3.5 \% \mathrm{P}, 10 \% \mathrm{~K}, 1.2 \% \mathrm{Mg}, 5 \% \mathrm{~S}$ and micronutrients) were applied right after sowing at two $\mathrm{N}$ fertilization levels (10 and $20 \mathrm{~g} \mathrm{~N} \mathrm{~m}^{-2}$ ) (10 CAN, $10 \mathrm{DF}$, $20 \mathrm{CAN}, 20 \mathrm{DF}$ ) supplemented by an unfertilized control. Maximum temperature from sowing to harvest was $35.5^{\circ} \mathrm{C}(2006)$ and $37.9^{\circ} \mathrm{C}(2007)$; minimum temperature was $4.9^{\circ} \mathrm{C}(2006)$ and $3.1^{\circ} \mathrm{C}(2007)$.

\section{Crop management and measurements}

Seeds were sown with an Oyjard plot drill (row distance: $12 \mathrm{~cm}$; plots size: $30 \mathrm{~m}^{2}$ ). Chickpea nodulates with symbiotic bacteria Mesorhizobium cicieri and $M$. mediterraneum (Toker et al., 2007), and therefore, seeds were inoculated with Mesorhizobium ciceri (Jost GmbH), seeds of pea with Rhizobium leguminosarum (Radicin No4, Jost $\mathrm{GmbH}$ ) according to product specifications before sowing. Inoculation was performed as eastern Austrian soils may not contain the specific rhizobia for chickpea to ensure an effective plant-microbe association for nitrogen fixation. Inoculation of chickpea seeds has been shown to increase yield and protein content of seeds (El Hadi and Elsheikh, 1999; Farzaneh et al., 2009). Sowing was performed on 14 April 2006 and on 11 April 2007, respectively, with a sowing rate of 90 seeds $\mathrm{m}^{-2}$ for chickpea and pea and 300 seed $\mathrm{m}^{-2}$ for barley and oat. Weed control was performed mechanically. Aboveground dry matter (AGDM) development was determined by harvesting $\left(0.24 \mathrm{~m}^{2}\right.$ per plot) at intervals of about 14 days from May until the end of June (2006: 5 May, 22 May, 9 June, 27 June; 2007: 14 May, 31 May, 14 June, 26 June). The final harvest was performed at full ripeness of the plants on $0.96 \mathrm{~m}^{2}$ per plot (chickpea: 1 August 2006 and 23 July 2007; pea: 20 July 2006 and 9 July 2007; barley: 18 July 2006 and 23 July 2007; oat: 24 July 2006 and 23 July 2007). Plant samples were dried at $100^{\circ} \mathrm{C}$ for $24 \mathrm{~h}$. 


\section{Nitrogen determination and calculations}

For nitrogen determination, plant samples were first ground to pass through a $1 \mathrm{~mm}$ sieve. Nitrogen concentrations were determined as an average of duplicate samples per plot of about $500 \mathrm{mg}$ each with a combustion technique using a LECO-2000CN auto analyzer (LECO, 1994).

Crop nitrogen uptake rate $\left(\mathrm{CUR}_{\mathrm{N}}\right)$ and relative nitrogen uptake rate $\left(R_{U} R_{N}\right)$ were calculated for each period between subsequent harvest dates according to Hunt (2002) as follows:

$$
\begin{aligned}
& \text { (1) } \operatorname{CUR}_{\mathrm{N}}\left(\mathrm{g} \mathrm{m}^{-2} \mathrm{~d}^{-1}\right)=\frac{\mathrm{N}_{2}-\mathrm{N}_{1}}{\mathrm{t}_{2}-\mathrm{t}_{1}} \\
& \text { (2) } \operatorname{RUR}_{\mathrm{N}}\left(\mathrm{mg} \mathrm{g}^{-2} \mathrm{~d}^{-1}\right)=\frac{\ln \mathrm{N}_{2}-\ln \mathrm{N}_{1}}{\mathrm{t}_{2}-\mathrm{t}_{1}}
\end{aligned}
$$

where $\mathrm{N}_{2}$ and $\mathrm{N}_{1}$ indicate the final and initial nitrogen yield of the AGDM and $t_{2}$ and $t_{1}$ indicate the end and the start day of each period.

\section{Statistics}

Statistical analyses were performed using software SAS version 9.2. Analyses of variance (PROC GLM) with subsequent multiple comparisons of means were performed. Means were separated by least significant differences (LSD), when the F-test indicated factorial effects on the significance level of $\mathrm{p}<0.05$. Genotype differences within chickpea and pea, respectively, were not significant, so data were pooled for analysis.

\section{RESULTS AND DISCUSSION}

Data are presented for $\mathrm{N}$ fertilization (main effect) and interaction of crop $\times$ year based on analysis of variance results.

\section{Above-ground dry matter production (AGDM)}

Growth and yield analysis of chickpea compared to pea, barley and oat have been already described by Neugschwandtner et al. (2013). In both years until end of June (HD 4), the AGDM of chickpea was significantly lower than those of pea, barley and oat. Final AGDM (HD 5) of chickpea in 2006 was significantly lower than those of the other crops. With dry conditions in 2007, chickpea's final AGDM was less impaired than those of the other crops resulting in similar levels of AGDM in all four crops as chickpea is well adapted to drought stress (Serraj et al., 2004; Cutforth et al., 2009; Zaman-Allah et al., 2011) (Figs. 1a-e). Fertilization with readily available CAN enhanced early AGDM production (HD 2) of all crops compared to the unfertilized controls. The DF treatments resulted in intermediate AGDM. At HD 3 and 4 all $\mathrm{N}$ fertilization regimes had higher AGDM than the controls. Also at final harvest (HD 5), fertilizer regimes 20 CAN, $10 \mathrm{CAN}$ and $20 \mathrm{DF}$ had higher AGDM than control (with 10 DF lying in between) (Table 2). Early $\mathrm{N}$ application may cause sufficient plant and root development and thereby enables a better adaptation to the post anthesis drought stress (Gevrek and Atasoy, 2012).

Table 2. Above-ground dry matter (AGDM), N concentration and $\mathrm{N}$ yield during crop development as affected by fertilization

\begin{tabular}{|c|c|c|c|c|c|}
\hline \multirow{3}{*}{$\frac{\text { AGDM yield }}{\left(\mathrm{g} \mathrm{m}^{-2}\right)}$} & \multicolumn{5}{|c|}{ Harvest dates } \\
\hline & \multirow[t]{2}{*}{1} & \multirow[t]{2}{*}{2} & \multirow[t]{2}{*}{3} & \multirow[t]{2}{*}{4} & \multirow[t]{2}{*}{5} \\
\hline & & & & & \\
\hline 0 & $38^{\mathrm{a}}$ & $127^{\mathrm{b}}$ & $360^{\mathrm{b}}$ & $632^{\mathrm{b}}$ & $954^{\mathrm{b}}$ \\
\hline $10 \mathrm{CAN}$ & $37^{\mathrm{a}}$ & $154^{\mathrm{a}}$ & $433^{\mathrm{a}}$ & $805^{\mathrm{a}}$ & $1115^{\mathrm{a}}$ \\
\hline $10 \mathrm{DF}$ & $37^{\mathrm{a}}$ & $142^{\mathrm{ab}}$ & $437^{\mathrm{a}}$ & $756^{\mathrm{a}}$ & $1058^{\mathrm{ab}}$ \\
\hline $20 \mathrm{CAN}$ & $37^{\mathrm{a}}$ & $156^{\mathrm{a}}$ & $454^{\mathrm{a}}$ & $820^{\mathrm{a}}$ & $1156^{\mathrm{a}}$ \\
\hline $20 \mathrm{DF}$ & $37^{\mathrm{a}}$ & $147^{\mathrm{ab}}$ & $440^{\mathrm{a}}$ & $828^{\mathrm{a}}$ & $1130^{\mathrm{a}}$ \\
\hline \multicolumn{6}{|c|}{ N concentration $(\%)$} \\
\hline 0 & $4.46^{\mathrm{d}}$ & $3.40^{\mathrm{e}}$ & $2.87^{\mathrm{c}}$ & $2.28^{\mathrm{b}}$ & $1.85^{\mathrm{b}}$ \\
\hline $10 \mathrm{CAN}$ & $5.05^{\mathrm{ab}}$ & $4.65^{b}$ & $3.27^{\mathrm{b}}$ & $2.39^{\mathrm{b}}$ & $1.94^{\mathrm{ab}}$ \\
\hline $10 \mathrm{DF}$ & $4.83^{c}$ & $4.14^{\mathrm{d}}$ & $3.02^{\mathrm{c}}$ & $2.36^{\mathrm{b}}$ & $1.88^{\mathrm{b}}$ \\
\hline $20 \mathrm{CAN}$ & $5.15^{\mathrm{a}}$ & $4.95^{\mathrm{a}}$ & $3.59^{\mathrm{a}}$ & $2.67^{\mathrm{a}}$ & $2.11^{\mathrm{a}}$ \\
\hline $20 \mathrm{DF}$ & $4.98^{b}$ & $4.37^{\mathrm{c}}$ & $3.25^{\mathrm{b}}$ & $2.45^{\mathrm{b}}$ & $1.96^{\mathrm{ab}}$ \\
\hline
\end{tabular}
(in $\mathrm{g}$ fertilizer $\mathrm{N} \mathrm{m}^{-2}$ ) (means across crops and years)

\section{$\underline{N \text { yield of } A G D M}$}

$\left(\mathrm{g} \mathrm{N} \mathrm{m}^{-2}\right)$

\begin{tabular}{llllll}
\hline 0 & $1.78^{\mathrm{a}}$ & $4.9^{\mathrm{d}}$ & $10.1^{\mathrm{c}}$ & $14.3^{\mathrm{b}}$ & $16.9^{\mathrm{b}}$
\end{tabular}

$\begin{array}{llllll}10 \mathrm{CAN} & 1.94^{\mathrm{a}} & 6.9^{\mathrm{ab}} & 13.2^{\mathrm{b}} & 18.1^{\mathrm{a}} & 19.9^{\mathrm{ab}}\end{array}$

$\begin{array}{llllll}10 \mathrm{DF} & 1.88^{\mathrm{a}} & 5.8^{\mathrm{c}} & 12.7^{\mathrm{b}} & 17.4^{\mathrm{a}} & 18.5^{\mathrm{b}}\end{array}$

$\begin{array}{llllll}20 \mathrm{CAN} & 1.97^{\mathrm{a}} & 7.6^{\mathrm{a}} & 15.7^{\mathrm{a}} & 19.7^{\mathrm{a}} & 22.5^{\mathrm{a}}\end{array}$

$20 \mathrm{DF} \quad 1.90^{\mathrm{a}} \quad 6.3^{\mathrm{bc}} \quad 13.6^{\mathrm{b}} \quad 19.0^{\mathrm{a}} \quad 19.9^{\mathrm{ab}}$

CAN: calcium ammonium nitrate; DF: depot fertilizer Basacote ${ }^{\circledR}$ Plus $6 \mathrm{M}$. Different letters indicate significant differences between means ( $\mathrm{p}<$ $0.05)$.

\section{$N$ concentrations and $N$ yields of above-ground dry matter}

The $\mathrm{N}$ concentrations (\%) of the AGDM generally decreased with plant growth. Starting with HD 3 the N concentrations of all crops were higher in the dry year of 2007 compared to 2006. The $\mathrm{N}$ concentrations of chickpea in 2006 were lower than those of pea at early growth (HD 1 and 2) and at final harvest (HD 5); but they were higher than those of barley and oat at HD 3 and 4. In 2007, chickpea's $\mathrm{N}$ concentrations were always higher than those of barley and pea (except for HD 1); at HD 2 they were similar to, at HD 3 and 4 higher and at HD 5 lower than those of pea (Figs. 1f-j). The $\mathrm{N}$ concentrations of AGDM were increased by $\mathrm{N}$ fertilization at HD 2 in the following order: $20 \mathrm{CAN}>10 \mathrm{CAN}>20 \mathrm{DF}>10 \mathrm{DF}>$ control; thus, easily soluble $\mathrm{N}$ fertilizer CAN increase $\mathrm{N}$ concentrations more strongly at early growth compared to DF. At final harvest, the $\mathrm{N}$ concentrations were significantly higher in the $20 \mathrm{CAN}$ treatment than in the $10 \mathrm{DF}$ and control treatments (with $20 \mathrm{DF}$ and $10 \mathrm{CAN}$ lying in between) (Table 2). Differences between $\mathrm{N}$ concentrations during crop growth between years and fertilizer levels have already been reported for oat by Maral et al. (2012). Turpin et al. (2002) reported higher $\mathrm{N}$ concentrations in the AGDM of chickpea due to $\mathrm{N}$ fertilization during crop growth until flowering stage in experiments conducted in Australia. Contrary to that, 
higher $\mathrm{N}$ rates in our experiment resulted in higher $\mathrm{N}$ concentrations until maturity.

The $\mathrm{N}$ yield is a function of AGDM production and $\mathrm{N}$ concentration. Up to about the middle of June (HD 3), $\mathrm{N}$ yields were generally higher in 2007 than in 2006 (except for oat), mainly due to higher $\mathrm{N}$ concentrations and with pea and barley also due to higher AGDM. At the end of June (HD 4) chickpea, barley and oat still achieved higher $\mathrm{N}$ yields in 2007 compared to 2006 despite drought stress due to significantly higher $\mathrm{N}$ concentrations. Strongly impaired final AGDM of pea, barley and oat in 2007 resulted in a lower $\mathrm{N}$ yield compared to 2006 (although $\mathrm{N}$ concentrations of AGDM of these crops were higher in 2007). In contrast, chickpea was able to compensate slightly lower AGDM in 2007 by increased $N$ concentrations, resulting in a higher $\mathrm{N}$ yield than in 2006 (Figs. 1k-o). $\mathrm{N}$ fertilization clearly affected $\mathrm{N}$ yields during crop growth. At early growth (HD 2), N yields were high especially in treatments fertilized with CAN. At final harvest, the $\mathrm{N}$ yield of AGDM was significantly higher in the $20 \mathrm{CAN}$ treatment than in the $10 \mathrm{DF}$ and control treatments (with $20 \mathrm{DF}$ and $10 \mathrm{CAN}$ lying in between) (Table 2). Soltani et al. (2006) and Koutroubas et al. (2009) reported that variations of the $\mathrm{N}$ yield of chickpea were mainly linked to corresponding AGDM variations. Contrary to that, our results show that variations of both AGDM production and $\mathrm{N}$ concentrations affected the $\mathrm{N}$ yields of the crops. Furthermore, Caliskan et al. (2013) reported that fertilization also increases harvest indices and protein yields of chickpeas.

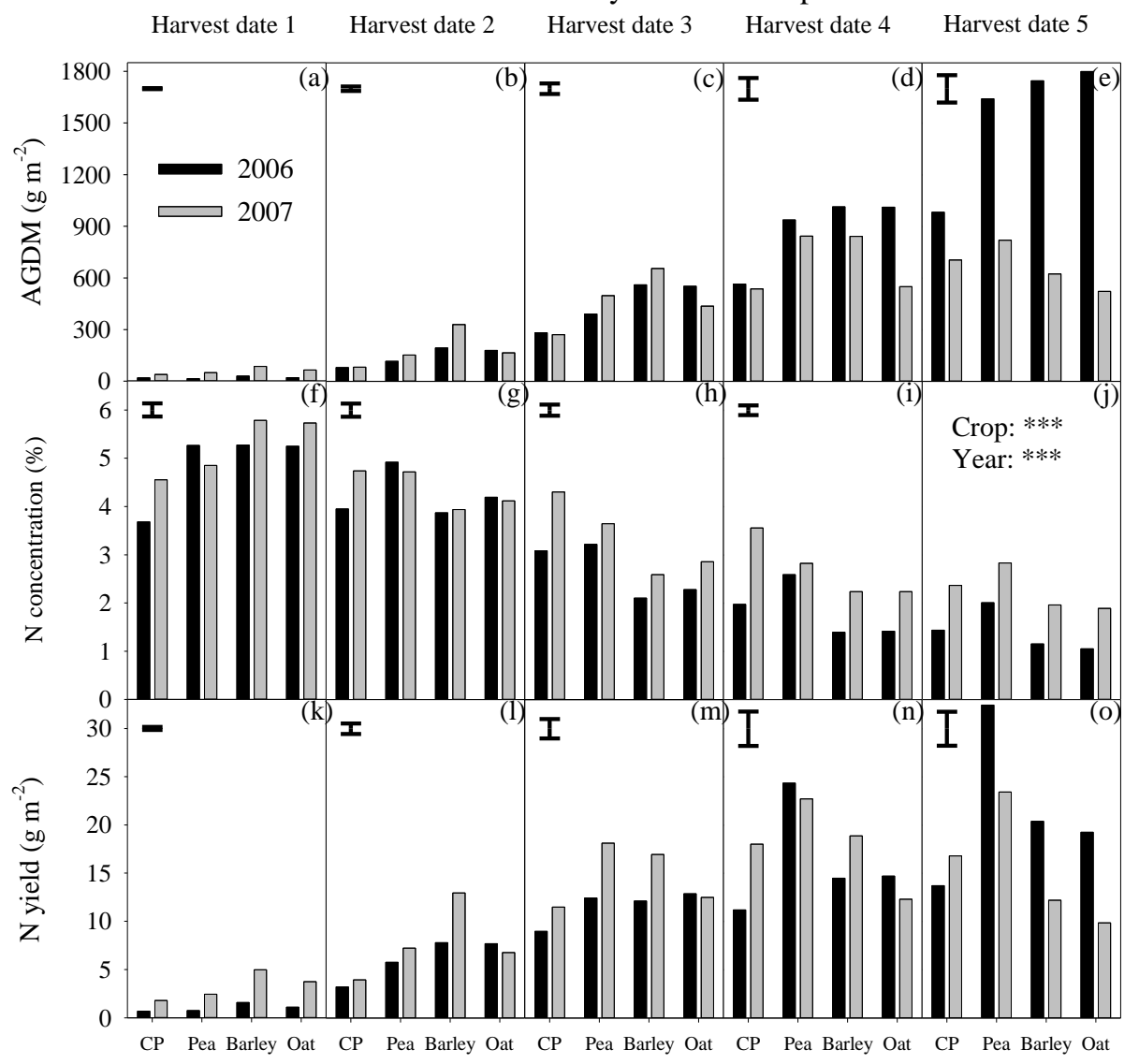

Figure 1. (a-e) Above-ground dry matter (AGDM), (f-j) $\mathrm{N}$ concentration and (k-o) $\mathrm{N}$ yield on harvest dates 1-5 as affected by crop and year. Error bars are LSD. CP = chickpea.

\section{Crop nitrogen uptake rate $\left(C U R_{N}\right)$ and relative nitrogen uptake rate $\left(R U R_{N}\right)$}

The $\mathrm{CUR}_{\mathrm{N}}$ of chickpea was lowest in the first observation period (HD 1-2) among the tested crops (except for oat in 2007). Between HD 2-3 chickpea's CUR $_{N}$ was lower than that of pea but higher than those of the cereals. In the more humid year of 2006 the $\mathrm{CUR}_{\mathrm{N}}$ of chickpea was the lowest among the four crops starting from middle of June (HD 3) until harvest; however, with dry conditions in 2007, chickpea's CUR $_{N}$ was clearly higher than those of the other crops between HD 3-4. The
CUR $_{N}$ was significantly lower in the dry year of 2007 than in 2006 in the last sampling period (HD 4-5) with negative values for chickpea, barley and oat and just a slightly positive value for pea (Figs. 2a-d). Drought stress significantly reduces the $\mathrm{CUR}_{\mathrm{N}}$ as described for wheat (Triticum aestivum L.) by Abreu et al. (1993). A negative CUR $_{N}$ during seed development until maturity has also been reported for oilseed rape (Brassica napus L.) by Barłóg and Grzebisz (2004). A high variability of the $\mathrm{CUR}_{\mathrm{N}}$ between crops, years and during crop development is in accordance with Gastal and Lemaire (2002). N fertilization affected $\mathrm{CUR}_{\mathrm{N}}$ until middle of June. The 
amount and seasonal distribution of $\mathrm{N}$ uptake was affected by $\mathrm{N}$ rate and $\mathrm{N}$ form as reported by McTaggart and Smith (1995). There was a significant fertilization $\times$ year interaction on $\mathrm{CUR}_{N}$ between HD 1-2 insofar that $\mathrm{N}$ fertilization increased the $\mathrm{CUR}_{\mathrm{N}}$ with a higher increase after application of CAN than DF in 2006 whereas just the highest CAN treatment significantly increased $\mathrm{CUR}_{\mathrm{N}}$ in 2007 (data not shown); thus, easily soluble $\mathrm{N}$ fertilizer CAN increase $\mathrm{CUR}_{\mathrm{N}}$ more strongly than the DF at early growth. Between HD 2-3 the $\mathrm{CUR}_{\mathrm{N}}$ were ranked as follows: $20 \mathrm{CAN} \geq 20 \mathrm{DF}, 10 \mathrm{CAN}, 10 \mathrm{DF}>$ control. No differences in the $\mathrm{CUR}_{\mathrm{N}}$ after middle of June due to fertilization were observed (Table 3 ).

The RUR $\mathrm{N}_{\mathrm{N}}$ of chickpea was between HD 2-3 in both years slightly higher than that of peas and significantly higher than those of barley and oat; in the dry year of 2007 chickpea's RUR ${ }_{N}$ highly surpassed those of the other crops between HD 3-4. From end of June (HD 4) until final harvest (HD 5) all crops had a positive RUR in $^{2} 2006$ whereas in 2007 dry conditions caused a negative RUR $_{N}$ for the crops (with chickpea's RUR $\mathrm{N}_{\mathrm{N}}$ lying between pea's low negative $R_{U} R_{N}$ and the cereals' higher negative RUR $_{\mathrm{N}}$ ) (Figs. 2e-h). The RUR $\mathrm{N}_{\mathrm{N}}$ was increased with $\mathrm{N}$ fertilization between HD 1-2 in 2006 whereas no fertilizer effect was observed in 2007 (data not shown). No statistical differences in the RUR $\mathrm{N}_{\mathrm{N}}$ occurred between end of May (HD 2) and end of June (HD 4). The RUR between the last two harvest dates (HD 4-5) was impaired by $\mathrm{N}$ fertilization with $20 \mathrm{DF}$ compared with the control with all other $\mathrm{N}$ fertilization treatments having a slightly lower RUR $\mathrm{R}_{\mathrm{N}}$ than the control (Table 3).

Table 3. Crop nitrogen uptake rate $\left(\mathrm{CUR}_{\mathrm{N}}\right)$ and relative nitrogen uptake rate $\left(R U R_{N}\right)$ during crop development as affected by fertilization (in $\mathrm{g}$ fertilizer $\mathrm{N} \mathrm{m}^{-2}$ ) (means across crops and years)

\begin{tabular}{|c|c|c|c|c|}
\hline & \multicolumn{4}{|c|}{ Harvest dates } \\
\hline & $1-2$ & $2-3$ & $3-4$ & $4-5$ \\
\hline \multicolumn{5}{|l|}{$\operatorname{CUR}_{N}\left(\mathrm{~g} \mathrm{~m}^{-2} \mathbf{d}^{-1}\right)$} \\
\hline 0 & $0.18^{\mathrm{d}}$ & $0.34^{\mathrm{b}}$ & $0.29^{\mathrm{a}}$ & $0.11^{\mathrm{a}}$ \\
\hline $10 \mathrm{CAN}$ & $0.29^{\mathrm{ab}}$ & $0.41^{\mathrm{ab}}$ & $0.27^{\mathrm{a}}$ & $0.16^{\mathrm{a}}$ \\
\hline $10 \mathrm{DF}$ & $0.23^{\mathrm{cd}}$ & $0.45^{\mathrm{ab}}$ & $0.31^{\mathrm{a}}$ & $0.05^{\mathrm{a}}$ \\
\hline $20 \mathrm{CAN}$ & $0.33^{\mathrm{a}}$ & $0.51^{\mathrm{a}}$ & $0.26^{\mathrm{a}}$ & $0.14^{\mathrm{a}}$ \\
\hline $20 \mathrm{DF}$ & $0.26^{\mathrm{bc}}$ & $0.47^{\mathrm{ab}}$ & $0.30^{\mathrm{a}}$ & $0.09^{\mathrm{a}}$ \\
\hline
\end{tabular}

\section{$\underline{\operatorname{RUR}} \mathbf{N}\left(\mathbf{m g ~ m}^{-2} \mathbf{d}^{-1}\right)$}

\begin{tabular}{lllll}
0 & $63^{\mathrm{c}}$ & $48^{\mathrm{a}}$ & $23^{\mathrm{a}}$ & $7^{\mathrm{a}}$ \\
$10 \mathrm{CAN}$ & $83^{\mathrm{a}}$ & $46^{\mathrm{a}}$ & $22^{\mathrm{a}}$ & $2^{\mathrm{ab}}$ \\
$10 \mathrm{DF}$ & $74^{\mathrm{b}}$ & $54^{\mathrm{a}}$ & $18^{\mathrm{a}}$ & $3^{\mathrm{ab}}$ \\
$20 \mathrm{CAN}$ & $85^{\mathrm{a}}$ & $51^{\mathrm{a}}$ & $15^{\mathrm{a}}$ & $3^{\mathrm{ab}}$ \\
$20 \mathrm{DF}$ & $81^{\mathrm{ab}}$ & $52^{\mathrm{a}}$ & $24^{\mathrm{a}}$ & $-1^{\mathrm{b}}$ \\
\hline
\end{tabular}

CAN: calcium ammonium nitrate; DF: depot fertilizer

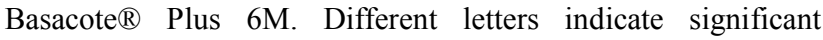
differences between means $(p<0.05)$.

Low and negative $\mathrm{CUR}_{\mathrm{N}}$ and $\mathrm{RUR}_{\mathrm{N}}$ before harvest may be due to ammonia $\left(\mathrm{NH}_{3}\right)$ volatilization from aboveground plant parts as observed by Bahrani et al. (2011) for wheat in the period from anthesis to maturity or due to leaf drop.

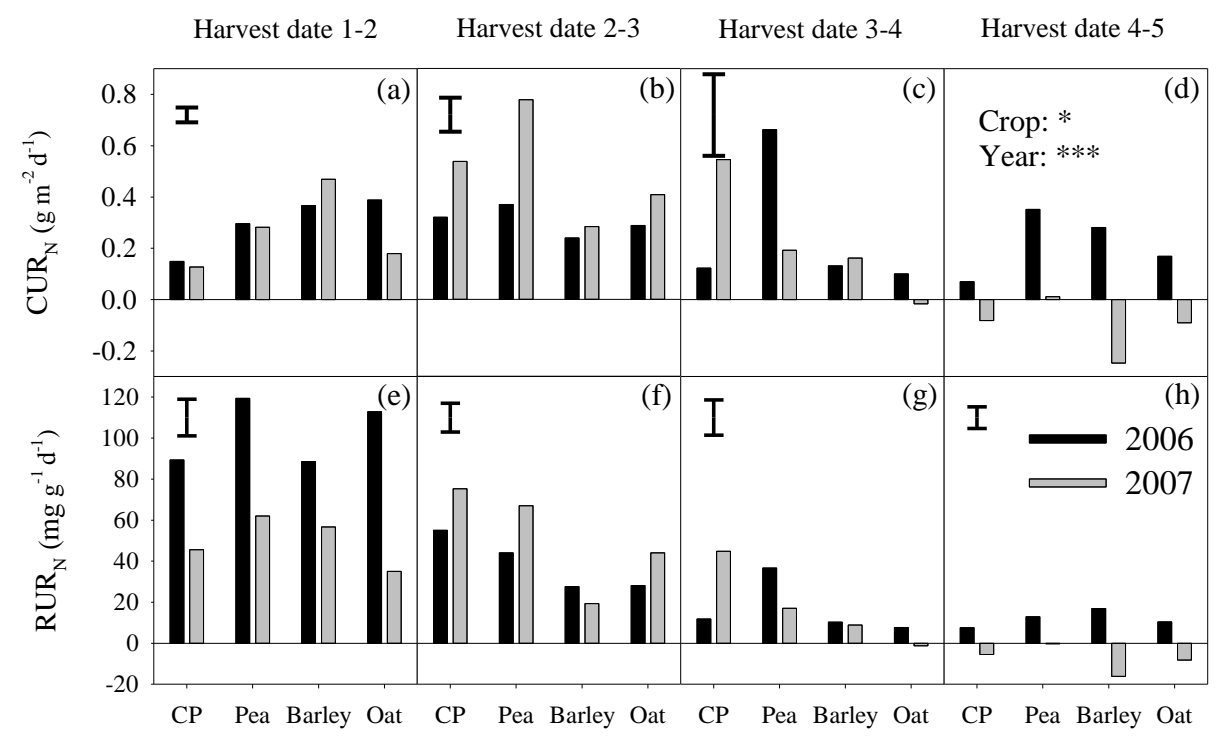

Figure 2. (a-d) Crop nitrogen uptake rate $\left(C U R_{N}\right)$ and $(e-h)$ Relative nitrogen uptake rate $\left(R U R_{N}\right)$ between the harvest dates as affected by crop and year. Error bars are LSD. CP = chickpea.

\section{CONCLUSION}

Chickpea had a lower AGDM in 2006 than pea, barley and oat but exceeded pea and oat in the dry year of 2007 due to its adaptability to drought stress. The $\mathrm{N}$ concentrations of all crops were higher in the dry year; however, chickpea was the only crop that could achieve a higher $\mathrm{N}$ yield as its AGDM was only slightly reduced under drought conditions. $\mathrm{N}$ fertilization clearly affected $\mathrm{N}$ concentrations and $\mathrm{N}$ yields of the crops during crop growth with CAN showing slightly higher $\mathrm{N}$ concentrations and $\mathrm{N}$ yields a final harvest than the DF. Chickpea showed a high $\mathrm{CUR}_{\mathrm{N}}$ and a high $\mathrm{RUR}_{\mathrm{N}}$ under drought conditions. Thus, results indicated that chickpea 
could be an alternative crop for achieving a reasonable $\mathrm{N}$ yield in dry Central European growing conditions.

\section{LITERATURE CITED}

Abreu, J.D.M., Flores, I., Abreu, F.D. and M. Madeira. 1993. Nitrogen uptake in relation to water availability in wheat. Plant Soil 154:89-96.

Anbessa, Y., Warkentin, T., Bueckert, R., Vandenberg, A. and Y. Gan. 2007. Post-flowering dry matter accumulation and partitioning and timing of crop maturity in chickpea in western Canada. Can J Plant Sci 87:233-240.

Bahrani, A., Abad, H.H.S. and A. Aynehband. 2011. Nitrogen remobilization in wheat as influenced by nitrogen application and post-anthesis water deficit during grain filling. Afr J Biotechnol 10:10585-10594.

Bampidis, V.A. and V. Christodoulou. 2011. Chickpeas (Cicer arietinum L.) in animal nutrition: A review. Anim Feed Sci Technol 168:1-20.

Barłóg, P. and W. Grzebisz. 2004. Effect of timing and nitrogen fertilizer application on winter oilseed rape (Brassica napus L.). II. Nitrogen uptake dynamics and fertilizer efficiency. J Agron Crop Sci 190:314-323.

Caliskan, S., Erdogan, C., Arslan, M. and M.E. Caliskan. 2013. Comparison of organic and traditional production systems in chickpea (Cicer arietinium L.). Turk J Field Crops 18:34-29.

Canci, H. and C. Toker. 2009a. Evaluation of annual wild Cicer species for drought and heat resistance under field conditions. Genet Resour Crop Ev 56:1-6.

Canci, H. and C. Toker. 2009b. Evaluation of yield criteria for drought and heat resistance in chickpea (Cicer arietinum L.). J Agron Crop Sci 195:47-54.

Cutforth, H.W., Angadi, S.V., McConkey, B.G., Entz, M.H., Ulrich, D. Volkmar, K.M., Miller, P.R. and S.A. Brandt. 2009. Comparing plant water relations for wheat with alternative pulse and oilseed crops grown in the semiarid Canadian prairie. Can J Plant Sci 89:823-835.

El Hadi, E.A. and E.A.E. Elsheikh. 1999. Effect of Rhizobium inoculation and nitrogen fertilization on yield and protein content of six chickpea (Cicer arietinum L.) cultivars in marginal soils under irrigation. Nutr Cycl Agroecosys 54:5763.

Farzaneh, M., Wichmann, S., Vierheilig, H. and H.-P. Kaul. 2009. The effects of arbuscular mycorrhiza and nitrogen nutrition on growth of chickpea and barley. Pflanzenbauwiss 13:15-22.

Gan, Y.T., Warkentin, T.D., McDonald, C.L., Zentner, R.P. and A. Vandenberg. 2009. Seed yield and yield stability of chickpea in response to cropping systems and soil fertility in northern latitudes. Agron J 101:1113-1122.

Gastal, F. and G. Lemaire. 2002. N uptake and distribution in crops: An agronomical and ecophysiological perspective. J Exp Bot 53:789-799.

Gevrek, M.N. and G.D. Atasoy. 2013. Effect of post anthesis drought on certain agronomical characteristics of wheat under two different nitrogen application conditions. Turk $\mathbf{J}$ Field Crops 17:19-23.

Henseler, M., Piot-Lepetit, I., Ferrari, E., Mellado, A.G., Banse, M., Grethe, H., Parisi, C. and S. Hélaine. 2013. On the asynchronous approvals of GM crops: Potential market impacts of a trade disruption of EU soy imports. Food Policy 41:166-176.

Hunt, R., Causton, D.R., Shipley, B. and A.P. Askew, 2002. A modern tool for classical plant growth analysis. Ann Bot 90:485-488

Kaul, H.-P. 2004. Pre-crop effects of grain legumes and linseed on soil mineral $\mathrm{N}$ and productivity of subsequent winter rape and winter wheat crops. Bodenkultur 55:95-102.

Koutroubas, S.D., Papageorgiou, M. and S. Fotiadis. 2009. Growth and nitrogen dynamics of spring chickpea genotypes in a mediterranean-type climate. J Agr Sci Camb 147:445458.

LECO Corporation. 1994. CN-2000 Carbon/Protein/Nitrogen Elemental Analyzer-Instruction Manual, Version 4. LECO Corporation, St. Joseph, MI, pp. 146.

McTaggart, I.P. and K.A. Smith. 1995. The effect of rate, form and timing of fertilizer $\mathrm{N}$ on nitrogen uptake and grain $\mathrm{N}$ content in spring malting barley. J Agric Sci Camb 125:341353.

Maral, H., Dumlupinar, Z., Dokuyucu, T. and A. Akkaya. 2012. Impact of genotype and nitrogen fertilization rate on yield and nitrogen use by oat (Avena sativa L.) in Turkey. Turk $\mathrm{J}$ Field Crops 17:177-184.

Miller, P.R., McConkey, B.G., Clayton, G.W., Brandt, S.A., Staricka, J.A., Johnston, A.M., Lafond, G.P., Schatz, B.G., Baltensperger, D.D. and K.E. Neill. 2002. Pulse crop adaptation in the northern Great Plains. Agron J 94:261-272.

Neugschwandtner, R.W., Wichmann, S., Gimplinger, D.M., Wagentristl, H. and H.-P. Kaul. 2013. Chickpea performance compared to pea, barley and oat in Central Europe: Growth analysis and yield. Turk J Field Crops 18:179-184.

Serraj, R., Krishnamurthy, L., Kashiwagi, J., Kumar, J., Chandra, S. and J.H. Crouch. 2004. Variation in root traits of chickpea (Cicer arietinum L.) grown under terminal drought. Field Crops Res 88:115-127.

Siddique, K.H.M. and J. Sykes. 1997. Pulse production in Australia: Past, present and future. Aust J Exp Agr 37:103111.

Soltani, A., Robertson, M.J., Rahemi-Karizaki, A., Poorreza, J. and H. Zarei. 2006. Modelling biomass accumulation and partitioning in chickpea (Cicer arietinum L.). J Agron Crop Sci 192:379-389.

Toker, C., Lluch, C., Tejera, N.A., Serraj, R. and K.H.M. Siddique, 2007. Abiotic stresses. In: Chickpea Breeding and Management (eds S.S. Yadav, B. Redden, W. Chen \& B. Sharma), CAB Int. Wallingford, UK, pp: 474-496.

Trnka, M., Eitzinger, J., Semerádová, D., Hlavinka, P., Balek, J., Dubrovský, M., Kubu, G., Štěpánek, P., Thaler, S., Možný, M. and Z. Žalud. 2011. Expected changes in agroclimatic conditions in Central Europe. Climatic Change 108:261-289.

Turpin, J.E., Herridge, D.F. and M.J. Robertson. 2002. Nitrogen fixation and soil nitrate interactions in field-grown chickpea (Cicer arietinum) and fababean (Vicia faba). Aust J Agric Res 53:599-608.

van Kessel, C. and C. Hartley. 2000. Agricultural management of grain legumes: has it led to an increase in nitrogen fixation? Field Crops Res 65:165-181.

Zaman-Allah, M., Jenkinson, D.M. and V. Vadez. 2011. A conservative pattern of water use, rather than deep or profuse rooting, is critical for the terminal drought tolerance of chickpea. J Exp Bot 62:4239-4252. 